\title{
MENELUSURI KESIAPAN LEMBAGA KEUANGAN MIKRO SYARIAH DALAM MENGHADAPI REVOLUSI INDUSTRI 4.0
}

\author{
Astri Furqani ${ }^{1}$ \\ Rusnani $^{2}$ \\ ${ }^{1}$ Fakultas Ekonomi dan Bisnis, Universitas Wiraraja, Indonesia \\ astri@wiraraja.ac.id \\ ${ }^{2}$ Fakultas Ekonomi dan Bisnis, Universitas Wiraraja, Indonesia \\ rusnani08@gmail.com
}

\begin{abstract}
Baitul Mal Wat-Tamwil (BMT) is a sharia microfinance institution. The current challenge for BMT is the change in the global business landscape based on the internet and information technology or the so-called industrial revolution 4.0. The phenomenon of the industrial revolution 4.0 must be anticipated by BMT. The purpose of this study is to determine the readiness of BMT in responding to the 4.0 industrial revolution and provide suggestions for improvement. This study used a qualitative approach with a descriptive type case study method of BMT which was used as a research site, namely BMT NU (Nuansa Umat) East Java which was centered in Gapura Tengah Village, Gapura District, Sumenep Regency due to its very rapid development and became the $B M T$ with the largest assets on Madura Island. . The results of the research are the readiness of BMT NU East Java in facing the era of the Industrial Revolution 4.0 when viewed from 6 existing aspects such as aspects of Economic Challenges, Social Challenges, Increased Virtual Performance, Technical Challenges, Environmental Challenges and Regulatory and Political Challenges all have gone very well, however technological developments / service innovations owned by BMT NU are not yet fully familiar among members / customers in utilizing these services so that there is a need for increased relationship management to better know the needs of the community and its members.
\end{abstract}

Keywrods: BMT, Sharia Microfinance Institutions, Industrial Revolution 4.0

\section{PENDAHULUAN}

Ekonomi Syariah merupakan cara pandang dan analisis untuk menyelesaikan permasalahan ekonomi dengan prinsip syariah Islam, yaitu berdasarkan atas $\mathrm{Al}$ Qur'an dan Hadits (P3EI, 2012:17). Ekonomi Syariah bertujuan untuk mencapai kebahagiaan di dunia dan akhirat serta tercapainya kebaikan dan kesejahteraan umat, dengan melakukan kegiatan ekonomi yang sesuai dengan syariat Islam. Implementasi ekonomi syariah salah satunya melalui lembaga keuangan syariah. Lembaga keuangan syariah sebagai bagian dari implementasi ekonomi syariah, harus menerapkan kegiatannya sesuai dengan syariat Islam.

Lembaga keuangan syariah salah satunya yaitu lembaga keuangan 
mikro syariah termasuk di dalamnya.

Salah satu lembaga keuangan mikro syariah adalah Baitul Mal watTamwil (BMT). Menurut Azis (2006) Baitul Mal Wat Tamwil dioperasikan oleh prinsip bagi hasil, untuk tumbuh dan berkembang usaha mikro dan kecil, dalam rangka meningkatkan dan mempertahankan martabat serta kepentingan kaum miskin. Manfaat BMT sangat dirasakan bagi masyarakat, terutama masyarakat lapisan bawah, karena BMT menerapkan sistem bagi hasil yang sesuai dengan prinsip syariah Islam dalam kegiatan simpan pinjamnya sehingga tidak memberatkan nasabah seperti praktek bunga pada lembaga keuangan konvensional.

Dengan adanya BMT ditengah masyarakat diharapkan mampu memberikan angin segar bagi usaha mikro dan kecil untuk lebih majusehingga menjadi penggerak perekonomian Indonesia.Tantangan BMT saat ini cukup berat, salah satunya yaitu perubahan lanskap bisnis global yang berbasis internet dan teknologi informasi atau disebut revolusi industri 4.0. Fenomena revolusi industri 4.0 harus diantisipasi oleh BMT. Revolusi Industri 4.0 menekankan enam prinsip utama dalam desain dan implementasinya yaitu Interoperabilitas, Virtualisasi, Desentralisasi, Kemampuan RealTime, Orientasi Layanan, dan Modularitas (Hermann et al.2015). Merespon revolusi industri 4.0, pengelolaan BMT dimasa mendatang akan diwarnai dengan berbagai penggunaan teknologi informasi.

Penggunaan teknologi informasi bagi BMT merupakan suatu keniscayaan di era revolusi industri 4.0, oleh karena itu menarik untuk diteliti mengenai kesiapan BMT dalam merespon revolusi industri 4.0. Selain itu, penelitian tentang kesiapan BMT dalam merespon revolusi industri 4.0 sependek pengetahuan peneliti masih belum dilakukan. BMT yang dijadikan sebagai situs penelitian yaitu BMT NU (Nuansa Umat) Jawa Timur yang berpusat di Desa Gapura Tengah Kecamatan Gapura Kabupaten Sumenep. Pemilihan BMT NU Jawa Timur sebagai situs penelitian dikarenakan perkembangannya yang sangat pesat dan menjadi BMT dengan aset terbesar di Pulau 
Madura. Modal awal sebesar Rp. 400.000,- di tahun 2004, kini di tahun 2019 aset BMT NU Jawa Timur mencapai Rp. 223 Miliar.

(https://www.nu.or.id/post/read/1025 67/modal-rp-400-ribu-aset-bmt-nukini-rp-2235-m).

Bagaimana kesiapan BMT NU Jawa Timur dalam menghadapi revolusi industri 4.0 inilah yang menjadi rumusan masalah penelitian ini. Penelitian ini menggunakan pendekatan kualitatif dengan metoda studi kasus tipe deskriptif agar informasi yang didapatkan lebih mendalam dan tujuan penelitian yaitu untuk mengetahui kesiapan BMT NU Jawa Timur dalam menghadapi revolusi industri 4.0 dapat tercapai. Kontribusi penelitian ini diharapkan sebagai bahan kajian bagi pengelola BMT NU Jawa Timur maupun BMT-BMT lainnya dalam mempersiapkan diri menghadapi revolusi industri 4.0.

\section{Lembaga Keuangan Mikro}

Salah satu upaya untuk mengentaskan kemiskinan di tengahtengah masyarakat saat ini yaitu dengan adanya program pembiayaan mikro. Dengan adanya pembiayaan mikro diharapkan dapat memberikan layanan yang lebih luas kepada usaha mikro kecil / masyarkat menengah kebawah yang belum memiliki aksesperbankan, sehingga keberadaan Lembaga keuangan mikro menjadi sebuah institusi yang tidak hanya profit motive tetapi juga memiliki sifat social motive.Lembaga Keuangan Mikro menurut Undang -undang No.1 Tahun 2013 adalah lembaga keuangan yang khusus didirikan untuk memberikan jasa pengembangan usaha dan pemberdayaan masyarakat, baik melalui pinjaman atau pembiayaan dalam usaha skala mikro kepada anggota dan masyarakat, pengelolaan simpanan, maupun pemberian jasa konsultasi pengembangan usaha yang tidak semata-mata mencari keuntungan. Dan Asian Development Bank mendefinisikan LKM (microfinance) adalah lembaga penyedia jasa penyimpanan, kredit, pembayaran berbagai transaksi jasa serta transfer uang yang ditujukan bagi masyarakat miskin dan pengusaha kecil. Sementara menurut Otero (1999) dalam Wrenn (2005) dikatakan bahwa yang dimaksudkan dengan lembaga keuangan mikro adalah suatu jasa keuangan yang 
akan memberikan manfaat dalam hal pemberian pinjaman, tabungan ataupun jasa keuangan lain yang layak dan bisa diberikan kepada masyarakat yang berpenghasilan rendah. Termasuk dalam hal ini adalah memberikan pinjaman yang sifatnya adalah memberikan mikro kredit bagi para nasabah yang memang memiliki penghasilan yang rendah.

Adapun bentuk-bentuk yang ada dari lembaga keuangan mikro adalah:1). lembaga formal seperti bank dan koperasi; 2). Lembaga semiformal misalnya organisasi non pemerintah; 3). Sumber-sumber informal misalnya pelepas uang. Akan tetapi sumber-sumber informal ini biasanya sangat rawan karena pengawasan yang kurang.Sedangkan menurut Bank Indonesia bentuk LKM dibagi menjadi 2 kategori, yaitu LKM berwujud bank dan LKM nonbank.Dan Baitul Mal wa atTamwil (BMT) merupakan salah satu contoh LKM nonbank

\section{Lembaga Keuangan Mikro Syariah}

Lembaga keuangan mikro Islam merupakan lembaga yang memperkenalkan sebagai pilihan untuk masyarakat yang memiliki penghasilan yang rendah untuk mendapatkan pembiayaan agar dapat meningkatkan taraf hidup dan keluar dari kemiskinan (Khadijah et al,2013).Rahman (2007) menyatakan bahwa lembaga keuangan mikro syariah merupakan satu hal yang tidak boleh diabaikan dalam perkembangan lembaga keuangan syariah karena terbukti sukses dalam melakukan pengentasan kemiskinan.Indonesia merupakan satu dari 4 negara yang dikategorikan sebagai leader dalam pengembangan keuangan mikro, termasuk keuangan mikro syariah.

\section{BMT}

Ridwan (2004) dalam Sapudin, A., Najib, M. dan Djohar S (2017) mendefinisikanBaitul Mal wa Tamwil menurut bahasa adalah rumah usaha, sedangkan pengertian yang menyeluruh bahwa BMT merupakan organisasi bisnis yang berperan sosial. Baitul mal berfungsi untuk mengumpulkan sekaligus juga untuk membagikan berbagai dana sosial. Sedangkan baitul tamwil merupakan lembaga bisnis yang bermotif laba.BMT merupakan gabungan dari baitul mal dan baitul 
tamwil.Baitul Mal wat tamwil juga merupakan satu suatu badan usaha mandiri yang bersifat terpadu. Tujuan BMT yaitu untuk mengembangkan berbagai usaha kegiatan produktif dan juga investasi dalam rangka meningkatkan kegiatan ekonomi dari para pengusaha kecil, menengah dan bawah dengan mendorong kegiatan pengembangan dan penimgkatan dana pihak ketiga serta menunjang pembiaayaan kegiatan ekonomi. Peran BMT yang merupakan lembaga sosial, juga sebagai baitul maal mempunyai kesamaan dari sisi fungsi juga peran dengan LAZ (Lembaga Amil Zakat), sehingga baitul maal harus dimotivasisupaya dapat berperan professional dan menjadi LAZ yang stabil. Fungsi tersebut setidaknya terdiri dari usaha pengumpulan danainfaq, zakat, sedekah, wakaf serta sumber pendanaan sosial lainnya, juga upaya dalam menyalurkan zakat sesuai dengan ketentuan Islam juga sesuai dengan dengan UU Nomor 38 ahun 1999.

\section{Revolusi Industri 4.0}

Sejarah revolusi industri dimulai dari industri 1.0, 2.0, 3.0, hingga industri 4.0. (Yahya,2018). Awal mula Istilah "Revolusi Industri" diperkenalkan oleh Friedrich dan Louis Auguste Blanqui pada pertengahan abad ke 18. (Latucosina,2017) dalam Wibowo. Revolusi Industri 1.0 terjadi di Inggris sekitar tahun 1760 yang ditandai dengan penggunaan uap untuk menggerakkan mesin.Revolusi industri 2.0 terjadi di Amerika Serikat dan Uni Soviet pada abad ke20 berupa produksi massal dan standarisasi mutu.Revolusi industri 3.0 yang ditandai dengan penggunaan teknik kimia-hayati berbahan bakar atom atau nuklir atau manufaktur berbasis otomasi dan robot.Terakhir, yang sedang berlangsung saat ini yaitu revolusi Industri 4.0 yang ditandai dengan cyber fisik dan kolaborasi manufaktur (Hermann et al, 2015; Irianto, 2017) dalam Yahya (2018).

Terdapat enam prinsip utama yang ditekankan dalam Revolusi Industri 4.0 baik desain dan juga implementasinya yaitu : Interoperabilitas, Virtualisasi, Desentralisasi, Kemampuan RealTime, Orientasi Layanan, dan Modularitas (Hermann et al, 2015). Revolusi industri 4.0 selain menjadi 
peluang, juga merupakan tantangan.

Tantangan Revolusi Industri 4.0 menurut Hecklau et al (2016)

disajikan dalam tabel berikut :

Tabel 1

Tantangan Revolusi Industri 4.0 menurut Hecklau et al (2016)

\begin{tabular}{|c|c|}
\hline Tantangan ekonomi & $\begin{array}{l}\text { Globalisasi yang terus berlanjut: kemampuan } \\
\text { antarbudaya, Keterampilan berbahasa, kelenturan waktu, } \\
\text { Keahlian jaringan dan paham akan proses } \\
\text { Meningkatnya kebutuhan akan pembaruan:pola pikir } \\
\text { wirausaha, daya kreasi,problem solving, Bekerja dalam } \\
\text { tekanan, Pengetahuan terkini, kemampuan teknis, } \\
\text { Kemampuan penelitian dan paham akan proses } \\
\begin{array}{l}\text { Permintaan untuk tujuan layanan yang lebih } \\
\text { tinggi:conflict solving, skil }\end{array} \text { komunikasi, } \\
\begin{array}{l}\text { Keterampilannegoisasidan Keterampilan membentuk } \\
\text { jaringan }\end{array} \\
\begin{array}{l}\text { Kebutuhan untuk kerja } \\
\text { berkolaborasi:Dapatbernegoisasi dan bekerja sama, } \\
\text { mampu bekerja dalam tim, keterampilan komunikasi dan } \\
\text { networking skill }\end{array}\end{array}$ \\
\hline Tantangan Sosial & $\begin{array}{l}\text { Perubahan demografi dan nilai sosial:Mampu } \\
\text { mentransfer pengetahuan, Penerimaan perputaran tugas } \\
\text { dan perubahan pekerjaan, Fleksibilitas tempat dan } \\
\text { waktusertamampu untuk memimpin } \\
\text { Peningkatan kerja virtual:Fleksibilitas tempat dan } \\
\text { waktu, Keterampilan teknologi, Keterampilan media } \\
\text { sertaPemahaman keamanan TI } \\
\text { Pertumbuhan kompleksitas proses:Kemampuan teknis, } \\
\text { paham akan proses, hasrat untuk belajar, Toleransi } \\
\text { ambiguitas, Pengambilan keputusan, problem solvingdan } \\
\text { Kemampuan analisis }\end{array}$ \\
\hline Tantangan Teknis & $\begin{array}{l}\text { Perkembangan teknologi dan penggunaan data } \\
\text { eksponensial:Keterampilan teknis, Kemampuan analisis, } \\
\text { Efisiensi dalam bekerja dengan data, Keterampilan koding, } \\
\text { Kemampuan memahami keamanan TI dan Kepatuhan } \\
\text { Menumbuhkan kerja kolaboratif:Mampu bekerja dalam } \\
\text { tim, Kemampuan komunikasi virtual, Keterampilan media, } \\
\text { Pemahaman keamanan TI dan mampun bersikap } \\
\text { kooperatif }\end{array}$ \\
\hline $\begin{array}{l}\text { Tantangan } \\
\text { Lingkungan }\end{array}$ & $\begin{array}{l}\text { Perubahan iklim dan kelangkaan sumber daya:Pola } \\
\text { pikir berkelanjutan, Keinginan untuk menjaga lingkungan } \\
\text { dan Kreativitas untuk mengembangkan solusi } \\
\text { keberlanjutan baru }\end{array}$ \\
\hline $\begin{array}{ll}\text { Tantangan } & \text { Politik } \\
\text { dan Aturan } & \end{array}$ & $\begin{array}{l}\text { Standarisasi:Kemampuan mengolah data,Paham akan } \\
\text { proses. Kemampuan teknis } \\
\text { Keamanan data dan privasi:Paham akankeamanan } \\
\text { teknologi informasi dan Kepatuhan }\end{array}$ \\
\hline
\end{tabular}




\section{METODE PENELITIAN}

\section{Jenis Penelitian}

Penelitian ini menggunakan pendekatan kualitatif dengan metode studi kasus tipe deskriptif analisis.Studi kasus tipe deskriptif menurut Yin (2011), mempunyai sifat memaparkan dengan tujuan untuk mendapatkan gambaran lengkap tentang peristiwa di tempat tertentu.

Alasan peneliti menggunakan pendekatan tersebut karena dalam penelitian ini peneliti berusaha mengungkapkan secara mendalam tentang permasalahan dan temuantemuan tentang kesiapan BMT NU Jawa Timur dalam menghadapi revolusi industri 4.0.dan menganalisis permasalahan tersebut beserta penyebabnya.

\section{Objek Penelitian}

Peneliti memilih BMT NU Jawa Timur sebagai situs penelitian dikarenakan perkembangannya yang sangat pesat dan menjadi BMT dengan aset terbesar di Pulau Madura. Dengan Modal awal sebesar Rp. 400.000,- pada tahun 2004, kini di tahun 2019 aset BMT NU Jawa Timur mencapai Rp. 223 Miliar.

\section{Informan Penelitian}

Peneliti menentukan tiga orang informan dalam penelitian ini yang dianggap paling mengetahui tentang penelitian yang dilakukan. Tiga informan tersebut terdiri dari satu orang direktur Utama BMT NU Jawa Timur dan satu orang di divisi IT, satu orang karyawan

Mengenai informan penelitian, secara lengkap disajikan dalam tabel informan sebagai berikut :

Tabel 2

Informan Penelitian

\begin{tabular}{|c|c|l|}
\hline NO & $\begin{array}{c}\text { NAMA } \\
\text { (Inisial) }\end{array}$ & \multicolumn{1}{|c|}{ KETERANGAN } \\
\hline 1 & MS & Direktur Utama BMT NU Jawa Timur \\
\hline 2 & HM & Divisi IT \\
\hline 3 & UB & Karyawan \\
\hline
\end{tabular}




\section{Teknik Pengumpulan Data}

Teknik pengumpulan data dalam studi kasus menggunakan triangulasi (gabungan) yaitu gabungan antara observasi (pengamatan), in depth interview (wawancara mendalam) dan dokumentasi. Dalam melakukan pengumpulan data, peneliti menggunakan instrumen penelitian yaitu buku catatan, alat perekam audio/ video dan kamera.Peneliti untuk menguji keabsahan data dalam penelitian ini menggunakan metode triangulasi yaitu dengan menguji konsistensi data yang dikemukakan informan dengan cara melakukan wawancara dengan materi yang sama akan tetapi di lain waktu. Selain itu peneliti mengonfirmasi pernyataan antara informan yang satu dengan informan yang lainnya apakah bertentangan atau sama hasilnya, dan jika bertentangan, apa penyebabnya.

\section{Analisis Data}

Analisis data dalam penelitian ini bertujuan untuk menggambarkan kesiapan beserta kendala yang dihadapi BMT NU Jawa Timur dalam menghadapi revolusi industri 4.0.Analisis data dapat digambarkan sebagai berikut :
1. Hasil wawancara dengan 3 orang informan dibuatkan transkrip. Transkrip tersebut untuk memudahkan analisis data hasil wawancara.

2. Data hasil wawancara untuk kemudian dianalisis dan dikelompokkan dan diklasifikasikan sesuai dengan kesamaan jenis data.

3. Data hasil wawancara yang telah dikelompokkan untuk kemudiandisandingkan dengan data hasil pengamatan dan analisis dokumen untuk memperoleh gambaran kesiapan BMT NU Jawa Timur dalam menghadapi revolusi industri 4.0 sekaligus mengidentifikasi dan menganalisis kendala yang dihadapi.

4. Setelah mengidentifikasi dan menganalisis kendala beserta penyebabnya, maka dapat diketahui kesiapan BMT NU Jawa Timur dalam menghadapi revolusi industri 4.0.

5. Rumusan masalah terjawab.

\section{HASIL PENELITIAN BMT NU Jawa Timur \\ Awal mula keberadaan BMT NU Jawa Timur yang berada di}


Kecamatan Gapura dikarenaka

keprihatinan pengurus MWC

Nahdatul Ulama Gapura

Timurterhadap masyarakat Sumenep

khususnya masyarakat yang berada

dikecamatan Gapura dengan semakin banyaknnya rentenir yang membebankan bunga hingga 50\% per bulan sehingga hal tersebut dirasakan masyarakat sangat mencekik dan menghambat perkembangan usaha dan perekonomian masyarakat.

Perkembangan BMT NU selama 15 tahun menunjukkan perkembangan yang cukup signifikan, hal ini di buktikan dengan beberapa prestasi yang telah di capai BMT NU Jawa Timur ditingkat propinsi maupun nasional. Di tingkat nasional diantaranya sebagai koperasi terbaik pada tahun 2014 , kategori penggerak ekonomi rakyat kecil tahun 2013 (MNCTV Pahlawan untuk Indonesia), kategori Pemberdayaan Ekonomi tahun 2012 (SCTV Liputan 6 Award), KSP Award kategori penumbuhan anggota dan aset tercepat tahun 2014. Sedangkan ditingkat propinsi pada tahun 2014 sebagai Juara 1 koperasi berprestasi, pada tahun 2010 sebagai

KJKS berkinerja terbaik

Perkembangan anggota diawal berdirinya pada tahun 2004 hanya 33 orang namun di tahun 2016 sudah mencapai 22.166, jumlah penabung sebanyak 37.231, jumlah peminjam sebanyak 24.687. Perkembangan asset (kekayaan yang dimiliki pada tahun 2004 sebesar 2.216.500 dan di tahun $2016 \quad$ sebesar 120.593.539.528,40. Dan jumlah tabungan ditahun 2004 hanya sebesar Rp. 44.500 namun ditahun 2016 telah mencapai Rp. 39.030.820.525, 57. Sedangkan pembiayaan ditahun 2004 sebesar Rp. 1.520.000 ditahun 2016 telah mencapai Rp. 58.795.875.186,86.

Tidak hanya di Kabupaten Sumenep ternyata BMT NU mampu berkembang hingga terdapat di 11 kabupaten yang berada di propinsi Jawa Timur. Untuk di kabupaten Sumenep saja telah memiliki kantor cabang sebanyak 17 kantor cabang.

\section{Produk BMT NU JawaTimur}

1. Tabungan
a. Simpanan Anggota (SIAGA)
b. Tabungan
Mudharabah
(TABAH) 
c. Simpanan Haji dan Umroh (SAHARA)

d. Simpanan

Ukhrawi

(TARAWI)

e. Simpanan Lebaran (SABAR)

f. Simpanan Berjangka wadiah Berhadiah (SAJADAH)

g. Simpanan Berjangka

Mudharabah (SIBERKAH)

2. Pembiayaan

a. Bai’ Bits Tsamani Al - Ajil (BBA)

b. Murabahah

c. Mudlarabah

d. Musyarakah

e. Al-Qadratul Hasan

f. Rahn (Gadai)

\section{Layanan On Line}

Seiring perkembangan jumlah layanan di 55 cabang yang berada di Jawa Timur tentunya BMT NU Jatim melakukan beberapa inovasi untuk meningkatkan layanan yakni berupa layanan On Line diantaranya :

a. M-BMT NU merupakan layanan untuk transaksi berupa info saldo, info pembiayaan, transfer antar bank dan transfer antar rekening BMT NU, pembayaran tagihan listrik dan telepon serta top up pulsa. b. Registrasi anggota .kini telah tersedia layanan Registrasi secara Online sehingga mempermudah masyarakat yang ingin mendaftar menjadi anggota.

c. Aplikasi tabungan. Pembukaan rekening tabungan di KSPP. Syariah BMT NU Jawa Timur dapat dilakukan secara Online tanpa harus datang ke kantor.

d. Pengajuan pembiayaan dapatdilakukan secara Online, Sehingga nasabah dapat mengajukan pembiayan tanpa harus datang ke kantor.

\section{Kesiapan BMT NU Jawa Timur dalam Menghadapi Revolusi Industri 4.0}

\section{Tantangan ekonomi}

Dalam menghadapi tantangan ekonomi BMT NU memiliki visi dan misi yang salah satunya adalah terbentuknya 100 kantor cabang pada tahun 2026 untuk mencakup pelayanan yang lebih luas lagi. Tentu saja dalam menghadapi tantangan ekonomi kedepannya melakukan bina usaha kepada anggotanya maupun melakukan penghimpunan dan penyaluran pembiayaan pada segmen UMKM baik secara perorangan maupun jamaah.Terlebih 
lagi di era digital seperti sekarang ini telah banyak upaya yang dilakukan oleh BMT NU Jawa Timur. Sebagaimana yang disampaikan oleh bapak MS selaku Direktur Utama

"dengan semakin meningkatnya jumlah anggota BMT NU yang saat ini sudah memiliki kantor cabang sebanyak 55 yang tersebar di wilayah Jawa Timur dimana untuk kabupaten Sumenep saja sudah memiliki 17 kantor cabang kami melakukan beberapa inovasi mulai dari IT keuangan secara on line di semua cabang BMT NU itu sudah mulai tahun 2010. Kemudian ditahun 2013 Mobile BMT NU, tahun 2016 IBMT NU ini khusus pengelola, registrasi On Line untuk tabungan dan pembiayaan ditahun 2018 dan yang terbaru di tahun 2019 kita baru saja meluncurkan BMT $N U-Q "$.

Beberapa inovasi yang telah dilakukan BMT NU Jawa Timur sejak tahun 2010 tidak lain bertujuan untuk meningkatkan pelayanan kepada masyarakat (gambar 4. ). Sehingga BMT NU Jawa Timur memberikan kemudahan seperti untuk registrasi secara on line baik tabungan maupun pembiayaan sehingga masyarakat tidak perlu repot-repot untuk datang ke kantor cabang untuk Membuka rekening tabungan KSPP. Syariah BMT NU Jawa TimurUntuk oreintasi pelayanan yang lebih baik ke depannya BMT NU Jawa Timur tentunya membutuhkan beberapa strategi untuk pemecahan masalah ataupun kemampuan berkompromi dan keterampilan berjejaring dan tentu saja hal tersebut akan sangat membantu untuk meningkatakan inovasi atau untuk memenuhi kebutuhan anggota/ nasabah. Seperti yang diketahu bahwa anggota/nasabah BMT rata-rata bertempat tinggal di Kecamatan yang bukan kota atau dipelosok desa, sehingga dibutuhkan suatu keterampilan khusus dalam menangani permasalahan di lapangan. Salah satu strategi yang dilakukan BMT NU Jatim sebagaimana yang disampaikan oleh bapak Masyudi

"BMT bisa sebesar seperti sekarang berkat kerjasama dari anggota sebagai penabung atau peminjam jadi untuk mengatasi dan mengantisipasi masalah masalah yang ditimbul di anggota, kita membentuk kelompok-kelompok anggota kecil yang disingkat dengan FORSA Forum Silahturrahmi Anggota. Jadi FORSA itu ada ditiap-tiap radius $50 \mathrm{~m}$ jarak antar rumahnya. Kemudian adalagi yang merupakan gabungan dari beberapa kelompok kecil itu namanya MASA Majelis Silahturahmi. Dengan adanya 
kelompok-kelompok tersebut anggota menjadi lebih terbuka misalkan ada permasalahan atau ada keluhan. Dari forum kelompok tersebut kita bisa mendapatkan masukan sehingga nantinya akan menjadi bahan evaluasi.

Pada tingkatan bawah BMT

NU Jawa Timur telah melakukan beberapa strategi untuk meningkatkan orientasi layanandengan membentuk beberapa kelompok kecil di lingkungan rumah-rumah penduduk yang berada disekitar kantor cabang BMT NU Jawa Timur. Sehingga dari kegiatan tersebut dapat menjadi jembatan pihak BMT untuk bisa bekerjasama dan berkolaborasi dengan beberapa pihak

Keberadaan BMT bagi masyarakat dirasakan sangat membantu perekonomian mereka. Dan BMT memberikan kemudahan untuk pengusaha-pengusaha kecil untuk menambah modal usaha melalui pembiyaan maupun bertransaksi dan memasarkan produk=produk anggota $\mathrm{BMT}$ sendiri sehingga memberikan dampak terhadap peningkatan penjualan dan kesejahteraan anggotanya yang ratarata berada dipedesaan.
Rahman (2007) menyatakan bahwa lembaga keuangan mikro syariah merupakan satu hal yang tidak boleh diabaikan dalam perkembangan lembaga keuangan syariah karena terbukti sukses dalam melakukan pengentasan kemiskinan.

\section{Tantangan Sosial}

Sebagian besar perusahaan mencurahkan banyak perhatian pada manajemen sumber daya manusia (human resource managrment). Apalagi di era globalisasi saat ini yang memiliki dinamika sosial cukup beragam dan tentu saja akan menjadi suatu tantangan tersendiri bagi perusahaan tidak terkecuali bagi BMT NU Jawa Timur. Sehingga dibutuhkan kemampuan mentransfer pengetahuan, Penerimaan rotasi tugas kerja dan perubahan pekerjaan yang terkait (toleransi ambiguitas) dan dibutuhkan Fleksibilitas waktu dan tempat dan keterampilan memimpin. Dan yang telah dilakukan oleh BMT selama ini dalam rangka peningkatan SDM sebagaimana yang disampaikan oleh direktur utama BMT NU Jawa Timur pada saat dilakukan wawancara sebagai berikut:

$$
\begin{array}{ll}
\text { "untuk } & \text { meningkatkan } \\
\text { pengetahuan dan kinerja yaa.. }
\end{array}
$$


tentu kita setiap 3 bulan sekali ada diklat. Untuk karyawan baru selama satu bulan magang dan 10 hari untuk berhak mendapatkan Induk Pengelola.

Pernyataan tersebut di atas jelas mengatakan bahwa BMT NU Jawa Timur melakukan peningkatan SDM secara terus menerus dan bahkan dilakukan secara rutin per 3 bulan untuk mengikutsertakan karyawannya dalam berbagai diklat. Bahkan untuk dapat memperoleh Induk pengelola melalui magang selama satu bulan dan dilanjutkan mengikuti diklat 10 hari.

Peningkatan kinerja SDM tentunya akan berdampak terhadap keberlangsungan suatu perusahaan itu sendiri dalam menghadapi tren demografis dan ekonomi sehingga perusahaan dapat berkembang dan memiliki beberapa unit usaha selain tabungan dan pembiayaan yaitu unit usaha swalayan NU. Keberadaan swalayan NU ini sangat dirasakan oleh masyarakat karena menyediakan beberapa kebutuhan sehari-hari dan memiliki harga yang cukup bersaing dengan harga pasar.

Karyawan yang bertugas di swalayan juga telah melalui pelatihan terkait dengan pelayanan swalayan mulai dari kasir, stok barang sampai dengan pelaporan keuangan. Hal tersebut terkait dengan peningkatan kinerja karyawan. Pelatihanpelatihan tersebut diharapkan dapat meningkatkan kinerja karyawan yang pada ujungnya akan berkontribusi terhadap peningkatan kinerja lembaga.

\section{Peningkatan kerja virtual}

Hampir semua perusahaan dewasa ini memiliki situs web. Dengan adanya situs Web mereka menawarkan informasi produk umum, pembelian secara on line dan berbagai promosi. Sehingga dengan adanya Web mampu memberikan fleksibilitas terhadap waktu dan tempat. BMT NU Jawa Timur juga telah memiliki website (bmtnujatim.com) untuk meningkatkan visibilitas dan menawarkan produk-produk dan memberikan informasi bagi pihakpihak yang berminat. Seperti yang terlihat dalam gambar dibawah ini:

Dalam website yang dimiliki terdapat beberapa menu seperti produk, cabang, layanan on line, tentang kami (berisi tentang sejarah BMT NU Jatim, visi misi, struktur organisasi, hukum syar'i), kontak 
dan bahasa (Indonesia, Inggris, arab). Selain itu kita bisa mendapatkan popular berita/artikel yang terkait segala kegiatan BMT NU Jatim.

Tantangan virtual tentunya menuntut untuk selalu uptodate terhadap informasi-informasi yang dapat diberikan oleh perusahaan kepada masyarakat. Sehingga dengan informasi yang uptodate akan memberikan trust kepada masyarakat. Pada BMT NU Jatim terlihat beberapa informasi tentang perkembangan yang masih belum di update. Perkembangan terakhir yang ditampilkan terkait perkembangan keuangan seperti asset, ekuitas, jumlah anggota, penabung,mitra hanya sampai ditahun 2016. Namun untuk beberapa informasi lainnya seperti berita/artikel yang terkait BMT NU Jatim sudah cukup update hal tersebut nampak pada menu Perkembangan Keuangan di website bmtnujatim.com.

BMT NU merencanakan untuk terus menerus melakukan pengembangan dan peningkatan kinerja virtualnya. Hal tersebut untuk mendukung peningkatan kinerja secara keseluruhan sekaligus untuk menghadapi tantangan zaman ke depan yang serba digital. Inovasi layanan digital akan selalu dilakukan dengan mengikuti perkembangan teknologi informasi yang tersaji melalui beberapa pemberitaan maupun melalui pengiriman personil IT untuk mengikuti pelatihanpelatihan terkait inovasi digital.

\section{Tantangan Teknis}

Perkembangan teknologi di era digital menuntut BMT NU Jatim untuk bisa meningkatkan pelayanan secara real time. Hal tersebut terbukti ditahun 2014 melakukan terobosan dan inovasi dalam mempermudah transaksi antar cabang bagi para anggotanya. BMT NU Jatim menghadirkan kartu SIBIJAK yang dapat dilakukan untuk transaksi antar Cabang BMT NU secara online dan real time. Dan inovasi selalukan secara terus menerus dan di tahun 2019 ini BMT NU Jatim telah meluncurkan BMT NU-Q. BMT Qimah (BMT-Q) merupakan produk uang eloktronik (e-money) BMT NU melalui aplikasi mobile. Sebagaimana yang disampaikan oleh bapak Masyudi :

"di BMT NU-Q kita memanfaatkan untuk bisa bayar apa saja dan disitu ada banyak fitur seperti isi pulsa, bayar tagihan listrik, PDAM, donasi, 
BPJS, dan kita juga bisa melakukan pembelian antar anggota. Jadi misal anggota ada yang punya usaha bisa menawarkan lewat aplikasi kami dan bertransaksi lewat $\mathrm{Hp}$ semacam buka lapaktapi khusus anggota saja. Jadi tujuan kita supaya untuk membantu anggota dalam memasarkan barang dagangannya."

Inovasi dalam tekhnologi yang telah dilakukan BMT NU Jatim sudah dilakukan dengan cukup baik namun semuanya masih dalam tahap penyempurnaan. Informasi mengenai Inovasi Layanan BMT NU Jawa Timur berupa banner dapat terlihat baik di dalam dan halaman kantor BMT sendiri. Sebagaimana yang dikatakan oleh salah satu karyawan UB

"fasilitas layanan online alhamdulillah setiap hari semakin meningkat diseluruh wilayah namun masih dalam tahap penyempurnaan. Jadi saat ini yang lebih dominan digunakan hanya dibeli pulsa, token listrik, transfer dan belanja."

Namun meningkatnya inovasiinovasi tekhnologi yang dilakukan oleh BMT NU Jatim sampai sejauh ini masih banyak masyarakat atau anggota yang belum mengetahui dan memanfaatkan layanan online tersebut. Menindaklanjuti fakta ini, maka manajemen akan semakin gencar melakukan sosialisasi terkait layanan digital BMT, sehingga diharapkan nasabah maupun masyarakat umum dapat menggunakan layanan digital secara maksimal.

\section{Tantangan lingkungan}

Ditengah-tengah era digital terkadang perusahaan melupakan dengan kondisi dilingkungan sekitar. Di BMT NU Jatim memiliki kebijakan yakni dari 20\% laba dari KSPP digunakan untuk beberapa kegiatan sosial. Bapak MS mengatakan bahwa 20\% dari laba diperuntukkan dibeberapa kegiatan ada banyak semisal membeli ambulance, bantuan untuk fakir miskin, anak yatim, kemudian untuk gutu ngaji, untuk perbaiki masjid. Sedangkan yang berkaitan dengan lingkungan ada bantuan tempat sampah di pasar di Pamekasan, selain itu bantuan sanitasi berupa kloset di Situbondo.

Kepedulian terhadap lingkungan merupakan wujud kepedulian BMT NU terhadap kondisi lingkungan setempat. Dengan adanya kepedulian tersebut, diharapkan kehadiran BMT NU 
dapat memberikan manfaat yang besar kepada masyarakat, tidak semata-mata hanya melalui layananlayanan ke-BMT-an saja.

\section{Tantangan politik dan aturan}

$\begin{array}{ccc}\text { Suatu } & \text { Organisasi } & \text { dalam } \\ \text { menghadapi } & \text { tantangan } & \text { politik }\end{array}$
tentunya dibutuhkan budaya korporat (corporate culture) didalam organisasi itu sendiri. Budaya korporat adalah sistem prinsip, keyakinan dan nilai. Falsafah manajemen, jaringan komunikasi, dan lingkungan serta praktik ditempat kerja semuanya mempengaruhi budaya korporat (Boone, Kurtz ;2017). Seperti yang diketahui bahwa BMT NU memiliki visi Terwujudnya BMT NU yang Jujur, Amanah, dan Profesional sehingga Anggun dalam Layanan, Unggul dalam Kinerja menuju terbentuknya 100 Kantor Cabang Pada Tahun 2026 untuk Kemandirian dan Kesejahteraan Anggota”. Sebagaimana yang dikatakan oleh MS:

"kita mengutamakan kejujuran, dan amanah dalam menjalankan organisasi ini dan sesuai dengan visi dari BMT NU sendiri karena dari awal mula berdirinya BMT $N U$ di Gapura ini berawal dari rasa prihatin dengan kesejahteraan masyarakat
Gapura. Makanya kita mengadakan Monitoring dan audit dilakukan tiap minggu oleh manager area sedangkan untuk uji kepatuhan dilakukan setiap bulan yang dilaksanakan oleh direktur."

Untuk bertahan dalam era revolusi industri 4.0 BMT NU Jatim hendaknya mulai memfokuskandiri terhadap manajemen hubungan (relationship management) dan memperluas aktivitas untuk membangun dan memelihara ikatan yang berkesinambungan dan saling memberikan keuntungan dengan anggota/nasabah dan beberapa pihaklainnya. Dalam manajemen hubungan ini BMT NU Jatim dapat menggabungkan pengetahuan tentang kebutuhan dan selera konsumen (anggota) dan menerapkan pemahaman tersebut untuk menjadi sedekat mungkin dengan konsumen. Oleh karena itu aktivitas - aktivitas yang dilakukan untuk bisa lebih dekat dengan konsumen lebih banyak berbasis tekhnologi yang berbentuk komunikasi yang dilakukan lewat internet dan telepon seluler. 
FAKULTAS EKONOMI DAN BISNIS UNIVERSITAS WIRARAJA - MADURA

KESIMPULAN

Berdasarkan hasil penelitian yang dilakukan, dapat disimpulakanbahwa kesiapan BMT NU Jawa Timur dalam menghadapi era revolusi Industri 4.0 sudah sangat baik. Hal tersebut dapat dilihat dari berbagai aspek seperti :

1. Tantangan ekonomi

Menghadapi tantangan

Ekonomi, BMT NU Jatim melakukan beberapa inovasi untuk meningkatkan layanan yakni berupa layanan On Line Mobile BMT NU (M-BMT NU), layanan Registrasi anggota secara Online, membuka rekening tabungan secara Online dan Pengajuan pembiayaan secara Online. Sehingga nasabah dapat mengakses layanan darimana saja tanpa perlu mendatangi Kantor BMT untuk melakukan proses pengajuan pembiayaan KSPP Syariah BMT NU Jawa Timur.

2. Tantangan sosial

BMT NU Jawa Timur dalam menghadapi tantangan sosial dilakukan dengan peningkatan SDM secara terus menerus dan bahkan dilakukan secara rutin per 3 bulan untuk mengikutsertakan karyawannya dalam berbagai diklat. Selain itu untuk memperkuat cakupan demografis, BMT NU Jawa Timur memiliki beberapa unit usaha selain tabungan dan pembiayaan yaitu unit usaha swalayan NU.

3. Peningkatan Kinerja virtual

BMT NU Jawa Timur juga telah memiliki website (bmtnujatim.com) untuk meningkatkan visibilitas dan menawarkan produk-produk dan memberikan informasi bagi pihak-pihak yang berminat. Website dibuat semenarik mungkin dengan menu yang memudahkan pengunjungnya. Selain itu, inovasi terus-menerus terkait IT juga dilakukan.

4. Tantangan Teknis

Menghadapi tantangan teknis, BMT NU Jatim di tahun 2019 telah meluncurkan BMT NU-Q. BMT Qimah (BMT-Q) merupakan produk uang eloktronik (e-money) BMT NU melalui aplikasi mobile. Hanya saja kendalanya yaitu masyarakat masih belum 
familier terhadap layanan online atau digital tersebut sehingga diperlukan kegiatan sosialisasi yang intens terhadap nasabah dan masyarakat.

5. Tantangan Lingkungan

BMT NU Jatim memiliki kebijakan $20 \%$ dari laba digunakan untuk beberapa kegiatan sosial seperti membeli ambulance, bantuan untuk fakir miskin, anak yatim, guru ngaji dan perbaikan Masjid. Sedangkan yang berkaitan dengan lingkungan berupa bantuan tempat sampah dan bantuan sanitasi (kloset). Hal tersebut sebagai bentuk kepedulian lembaga dalam memberikan manfaat untuk masyarakat.

6. Tantangan Politik dan Aturan Tantangan ini dijawab dengan penerapan budaya korporat (corporate culture) dalam penerapan visi BMT NU yaitu Terwujudnya BMT NU yang Jujur, Amanah, dan Profesional sehingga Anggun dalam Layanan, Unggul dalam Kinerja menuju terbentuknya 100 Kantor Cabang Pada Tahun 2026 untuk
Kemandirian dan Kesejahteraan Anggota. Setiap karyawan harus mengintegrasikan budaya kerja tersebut pekerjaannya sehari-hari dengan melaksanakannya sepenuh hati.

\section{SARAN}

Beberapa saran dari peneliti berkaitan dengan penelitian ini adalah sebagai berikut :

1. Diharapkan BMT NU Jawa Timur terus melakukan sosialisasi dan edukasi mengenai penggunaan teknologi dalam layanannya kepada semua Nasabah yang mayoritas merupakan masyarakat pedesaan yang mempunyai pengetahuan terbatas terhadap penggunaan teknologi. Hal gtersebut harus dilakukan dengan bahasa yang sangat mudah dimengerti.

2. Diharapkan BMT NU Jawa Timur menambahkan layanan pembayaran kebutuhan masyarakat terhadap pembayaran pajak seperti PBB dan Pajak Kendaraan Bermotor karena hal tersebut dapat menjadi nilai tambah bagi BMT NU Jawa Timur` 
3. Penelitian ini menggunakan pendekatan kualitatif untuk 1 objek penelitian yaitu BMT NU Jawa Timur. Diharapkan penelitian selanjutnya dapat memperluas cakupan objek penelitian mengenai tema Kesiapan LKMS dalam menghadapi Revolusi Industri 4.0.

\section{DAFTAR PUSTAKA}

Boone E Louis, Kurtz David. (2017) Pengantar Bisnis Komtemporer. Edisi 13 Buku 1. Salemba Empat.

Hecklau, Fabian., Galeitzke, Mila dan Kohl, Holger (2016). Holistic approach for human resource management in Industry 4.0. Procedia CIRP $54: 1-6$

Hermann, M., Pentek, T., \& Otto, B. (2015). Design Principles for Industrie 4.0 Scenarios : A Literature Review. Working Paper. Fakultät Maschinenbau Technische Universität Dortmund, Dortmund.

Khadijah S, Saleh NEP, Kamarudin MF, Haryadi A.( 2013). Sustainability of Islamic Micro Finance Institutions (IMFIs).Journal of Accounting and Finance.DOI. 10.13189/ujaf.2013.010205

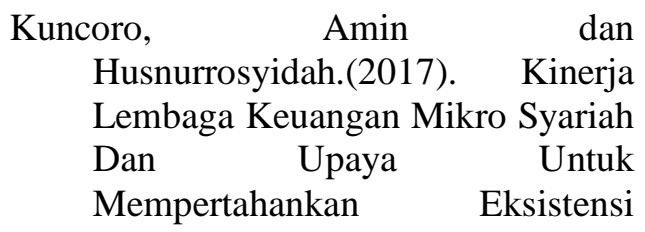

Perilaku Masyarakat Pedesaan.Jurnal Analisa Akuntansi dan Perpajakan, 1 (1) : 63-74

P3I(2012).Ekonomi Islam. P3I Yogyakarta

Republik Indonesia, Undang-undang No.1 Tahun 2013 tentang Lembaga Keuangan Mikro, Bab 1, Pasal 1

Rahardho, Mudjia.(2017). Studi Kasus Dalam Penelitian Kualitatif : Konsep Dan Prosedurnya. Program Pascasarjana Universitas Islam Negeri Maulana Malik Ibrahim Malang Program Pascasarjana.

Salama, Sri Cahyaning Umi. (2018). Babak Baru BMT di Indonesia.https://www.medcom.id/ ekonomi/analisaekonomi/5b2VgYvb-babak-barubmt-di-indonesia diakses 27 Februari 2019

Sapudin, A., Najib, M. dan Djohar, S. (2017). Strategi Pengembangan Lembaga Keuangan Mikro Syariah (Studi Kasus pada BMT Tawfin Jakarta). Jurnal Al-Muzara'ah 5(1).

Yahya, Muhammad. (2018). Era Industri 4.0: Tantangan Dan Peluang Perkembangan Pendidikan Kejuruan Indonesia. Disampaikan pada Sidang Terbuka Luar Biasa Senat Universitas Negeri Makassar

Yin, Robert K. (2011). Studi Kasus : Desain dan Metode. Rajagrafindo Persada. Jakarta.

https://www.nu.or.id/post/read/102567/ modal-rp-400-ribu-aset-bmt-nu-

kini-rp-2235-m diakses 27

